\title{
O Português Centro Histórico de São Francisco do Sul (BR): um atributo para o turismo cultural
}

\author{
The Portuguese Historical Center of São Francisco do Sul (BR): an \\ attribute for cultural tourism
Le Centre Historique de Portugais São Francisco do Sul (BR): un attribut pour le tourisme culturel
El Portugués Centro Histórico de São Francisco do Sul (BR): un atributo para el turismo cultural

\author{
Diva de Mello Rossini* \\ (divarossini@univali.br) \\ Luciano Torres Tricárico* \\ (tricarico@univali.br) \\ Carlos Alberto Tomelin* \\ (tomelin@univali.br)
}

Recebido em 07/04/2015, revisado e aprovado em 09/08/2015; aceito em 20/11/2015

DOI: http:/ / dx.doi.org/10.20435/1518-70122016111

\begin{abstract}
Resumo: Este artigo divulga a importância da preservação da memória e da identidade por meio da conservação do patrimônio histórico construído, o qual pode se tornar um atributo para o desenvolvimento do turismo cultural. Os locais de realização do estudo foram a Baixa Pombalina em Lisboa (PT) e o centro histórico de São 'Francisco do Sul (BR). O método aplicado foi de Rossini (2014), cujas categorias de analise da paisagem foram hierarquizadas por análise de redes sociais.

Palavras-chave: Patrimônio. Turismo cultural. Paisagem.

Abstrac: This paper discusses the importance of preserving the memory and the identity through the preservation of the historic built heritage, which can become an attribute for the development of cultural tourism. The studied places were Baixa Pombalina in Lisbon (PT) and the historic center of São Francisco do Sul (BR). The applied method was Rossini (2014), whose categories of landscape analysis were ranked by the analysis of social networks.

Key words: Heritage. Cultural tourism. Landscape.

Résumé: Cet article traite de l'importance de la préservation de la mémoire et de l'identité à travers la préservation du patrimoine bâti, qui peut devenir un attribut pour le développement du tourisme culturel. Les endroits étudiés étaient Baixa Pombalina à Lisbonne (PT) et le centre historique de São Francisco do Sul (BR). La méthode appliquée était Rossini (2014), dont les catégories d'analyse du paysage ont été classés par l'analyse des réseaux sociaux.

Mots-clé: Patrimoine. Le tourisme culturel. Paysage.

Resumen: En este trabajo se analiza la importancia de la preservación de la memoria y la identidad a través de la preservación del patrimonio arquitectónico histórico, que puede llegar a ser un atributo para el desarrollo del turismo cultural. Los lugares del estudio fueron la Baixa Pombalina de Lisboa (PT) y el centro histórico de São Francisco do Sul (BR). El método aplicado fue de Rossini (2014), cuyo análisis de las categorías de paisaje fueron calificados por el análisis de las redes sociales.

Palabras clave: Patrimonio. El turismo cultural. Paisaje.
\end{abstract}

\section{INTRODUÇÃO}

Uma das motivações para o desenvolvimento desta investigação foi o fato de o resultado poder contribuir com a sociedade do Brasil e de Portugal, divulgando a importância da preservação da memória e da identidade por meio da conservação do patrimônio histórico construído, o qual pode se tornar um atributo para o desenvolvimento do turismo cultural, um novo gerador de renda para a população residente.

E também devido à preocupação com a perda da identidade paisagística, representada pela arquitetura e pelo traçado urbano (YAZIGI, 2001), problemas gerados pelo desenvolvimento tecnológico aliado ao processo de globalização que vem promovendo a perda da memória e da identidade devido à massificação cultural e a

* Universidade do Vale do Itajaí (UNIVALI), Itajaí, Santa Catarina, Brasil. 
dizimação do patrimônio histórico edificado das cidades.

Os locais de estudo foram a Baixa Pombalina em Lisboa (PT) e o centro histórico de São Francisco do Sul (BR). O primeiro possui políticas públicas eficientes para a preservação e conservação do patrimônio histórico edificado e para o desenvolvimento do turismo cultural, e, no segundo, são poucas as iniciativas em prol da preservação da história edificada e a divulgação dela por meio do turismo cultural, no entanto, é a terceira cidade mais antiga do Brasil, colonizada por portugueses.

Para a investigação de campo foi utilizado o método de Rossini (2014), cujas categorias de análise da paisagem foram hierarquizadas por meio da análise de redes sociais. Após essa etapa, obteve-se uma tabela com as categorias observadas em cada uma das áreas de estudo, que identifica, nesses sítios, influências dos preceitos urbanísticos portugueses do século XVII.

Vale ressaltar que o sítio português já é reconhecido como um território turístico cultural consolidado, e o brasileiro não, embora os resultados obtidos apresentem significativa similaridade, fato que aponta a existência de potencialidades para o desenvolvimento do turismo cultural também no sítio brasileiro. Muitos foram os registros urbanos arquitetônicos encontrados no centro histórico de São Francisco do Sul (BR), análogos àqueles provenientes do plano elaborado e aplicado pela equipe do Marques de Pombal na reconstrução da Baixa Pombalina, Lisboa (PT).

O resultado desta investigação demonstra que São Francisco do Sul é uma cidade de origem portuguesa. E essa experiência poderá ser aplicada em outras localidades, pois o conteúdo gerado auxiliará a identificar potencialidades turísticas em outros locais, assim como a nortearem a elaboração de politicas públicas que contribuam com o desenvolvimento do turismo local e regional. Além de que, ao preservar os registros, a história edificada, estaremos contribuindo com a divulgação e perpetuação dos fatos que contam a evolução da sociedade brasileira, repleta de signos e peculiaridades culturais locais, que lhes confere autenticidade e as transforma em um produto cobiçado por investidores de diversas áreas. E também possibilita que esses novos territórios possam vir a compor roteiros culturais, dentre outras modalidades turísticas. Além de beneficiar a comunidade científica do Brasil, com a produção de novos conhecimentos nas áreas de Arquitetura e Patrimônio Histórico das Cidades - preservação, recuperação e revitalização da paisagem dos sítios históricos, e de Turismo - identificação de atributos para o desenvolvimento de novos destinos culturais, majorando a competitividade internacional da pesquisa brasileira.

Este artigo relata parte do resultado da pesquisa desenvolvida por um dos autores, durante o estágio pós-doutoral realizado na Universidade de Lisboa (PT), cujo projeto foi submetido e aprovado pelo edital CAPES/2013.

\section{O MÉTODO}

A pesquisa de campo é realizada por meio da aplicação do método de Rossini (2014), desenvolvido a partir dos conceitos de Kevin Lynch (1997), A imagem da cidade (1960); Gordon Cullen (1971), Paisagem da cidade (1961); Aldo Rossi (1995), A arquitetura da cidade (1966); Nuno Portas (2011), A cidade como Arquitetura (1969); Giulio Carlos Argan (2005), Projeto e destino (2001) e Roberto Boullón (2002), Planejamento do espaço turístico (2002).

Nessas obras, os autores debatem conceitos da Escola Italiana de Arquitetura, também intitulada de Escola de Veneza e discutem os referencias teóricos que foram aplicados nesta investigação. Vale ressaltar que todos esses estudiosos vivenciaram as transformações sociais que ocorreram na Europa, durante o período de implantação e desenvolvimento do movimento modernista, no inicio do século XX.

A seleção das principais categorias para análise da paisagem foi obtida por meio da construção de um sociograma, o qual demonstrou graficamente a atuação das categorias e suas conexões, figura 1 (NORMAN; ALEJANDRO, 2006). 


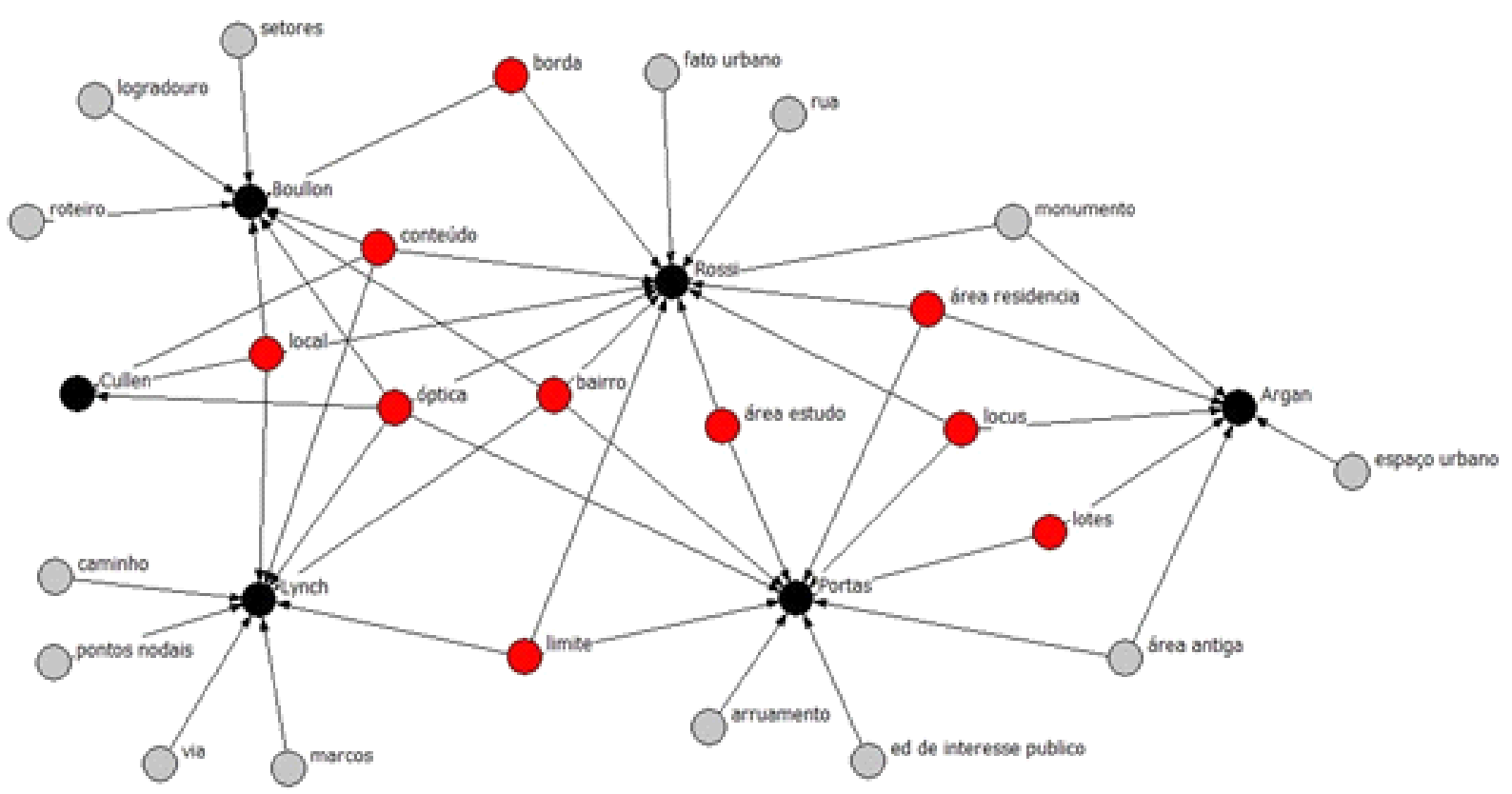

Figura 1 - Sociograma da rede de dois modos: conexões entre os autores e suas categorias de análise da paisagem.

Fonte: Elaborado pelos autores (2014).

A figura 1 apresenta as categorias de análise da paisagem que se interligam entre autores no sociograma e, por consequência, criam uma rede de vínculos completa, atribuindo a elas maior importância em uma escala hierárquica, quando comparada às demais. Portanto, para esta investigação, as categorias que foram selecionadas para serem aplicadas na pesquisa de campo foram: borda, conteúdo, local, ótica, bairro, limite, área estudo, área residência, lócus e lotes. Sendo elas discutidas nas publicações de Gordon Cullen (1971), Aldo Rossi (1995), Kevin Lynch (1997), Roberto Boullón (2002), Giulio Carlos Argan (2005) e Nuno Portas (2011).

\subsection{Aplicação do método na Baixa Pomba- lina, Lisboa (PT)}

A atual Baixa Pombalina foi uma das regiões de Lisboa mais atingidas pelo terremoto de 1755, que dizimou grande parte de Lisboa. Para reconstruir a cidade foi realizado um concurso para a escolha do melhor projeto, cuja organização ficou sob a responsabilidade do Marques de Pombal. Em dezembro desse mesmo ano, foram apresentados seis projetos com propostas para a reedificação da cidade, sendo que o plano vencedor estava baseado nos preceitos do modelo iluminista que vigorava na época. A partir dessa audaciosa proposta urbanística, assim vista por toda a Europa, a nova Lisboa passou a ser erguida (PEREIRA, 1994).

Os vencedores do concurso foram os arquitetos e engenheiros militares Manuel da Maia, Eugénio dos Santos e Carlos Mardel, todos participaram do levantamento e da execução dos projetos para erguer a nova cidade, sob a tutela da política pombalina. Esse plano urbanístico, figura 2, impunha um traçado geométrico ortogonal, com hierarquização de vias, definidas em função de duas praças principais, a Praça do Rossio, centro comunitário, e a Praça do Comércio, antigo Terreiro do Paço, centro político e econômico (MUSEU DA CIDADE, 2013). 


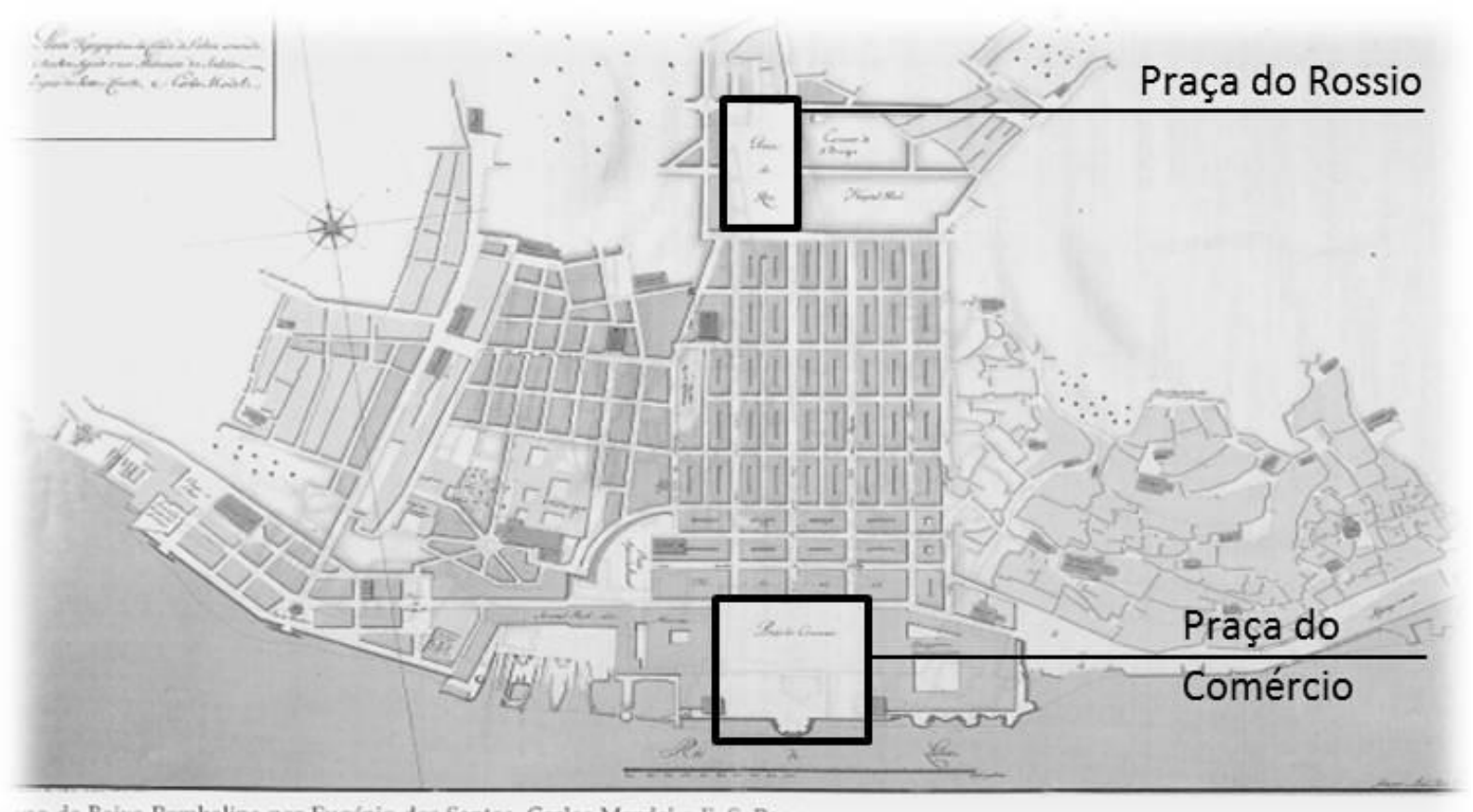

Figura 2 - Plano urbanístico para a reconstrução de Lisboa.

Fonte: Museu da Cidade (2013). Informações adicionadas pelos autores (2014).

O projeto de reconstrução prevê que as ruas podem ser classificadas como principais (tipo A), travessas (tipo B) e ruas secundárias (tipo C), sendo que cada uma corresponde à largura de 60, 40 e 30 palmos, respectivamente. Também foi previsto um padrão de fachada para cada tipologia construtiva. As ruas principais deveriam ter edifícios do tipo A, com cantarias recortadas em todas as portas e janelas, com ombreiras que simulam consoles, o arco da janela do terceiro andar, com a pedra inserida na cornija, o primeiro andar separado por uma faixa dos demais e com sacadas de pedra, com guarda corpo de ferro, ligados por um friso. Já o tipo B é uma variante deste com varandas no primeiro andar, mas sem a faixa separadora, com cantarias não recortadas e com ou sem fechamentos na janela do terceiro andar. E o tipo C, o mais simples, não tem varandas e as cantarias das janelas não são recortadas. No rés do chão, os vãos correspondem às lojas ou às entradas dos prédios, conjugando-se vergas curvas, retas ou com pequenos recortes nas extremidades. Cada caso deveria resolver as condicionantes da sua localização, adaptando-se não só à hierarquia dos espaços públicos, mas também às condições de variação de topografia, figura 3 . Os lotes eram regulados em módulos, o que permitia variar os seus tamanhos sem denunciar uma variação na fachada, que deveria apresentar-se contínua, tornando o quarteirão na unidade da composição urbana, embora admitindo uma série de combinações. As normativas previam uma coerência do todo, como a introdução dos novos andares ou os telhados duplos, introduzidos por Mardel na tipologia do Rossio (AUGUSTO-FRANÇA, 2009). 

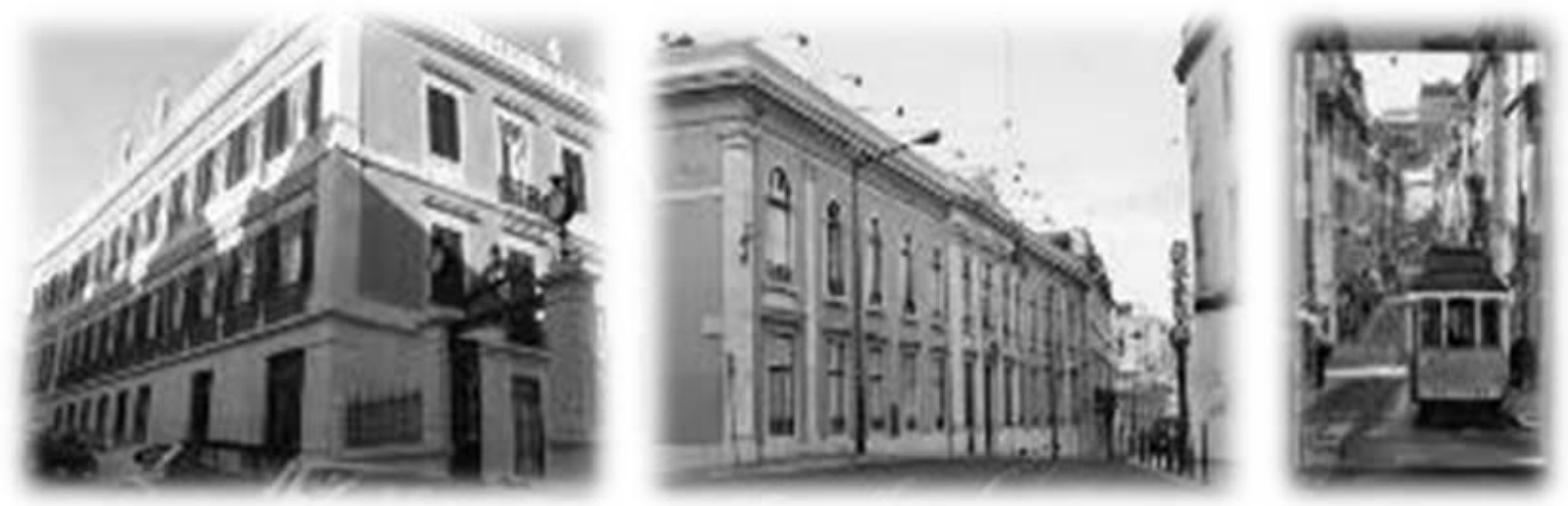

Figura 3 - Fachadas dos edifícios das ruas A, B e C, respectivamente.

Fonte: Ishizaka (2011).

Devido ao esmero do planejamento urbano de época que permanece, a região da Baixa Pombalina, área estudo, figura 4, é tema de várias discussões de âmbito político nacional. Segundo o Jornal da Construção, publicado em julho de 2010, a partir dos movimentos sociais em prol do reconhecimento da Baixa pombalina como Patrimônio da Humanidade, foi elaborado um Plano de Pormenor de Salvaguarda para essa região, o qual tem como intuito promover a requalificação urbana de uma área constituída, em grande parte, por edifícios devolutos e em mau estado de conservação, regulamentar as condições de intervenção nos edifícios e espaços públicos, bem como articular a cidade com a zona ribeirinha, criar equipamentos que complementem os já existentes e qualificar os espaços públicos.

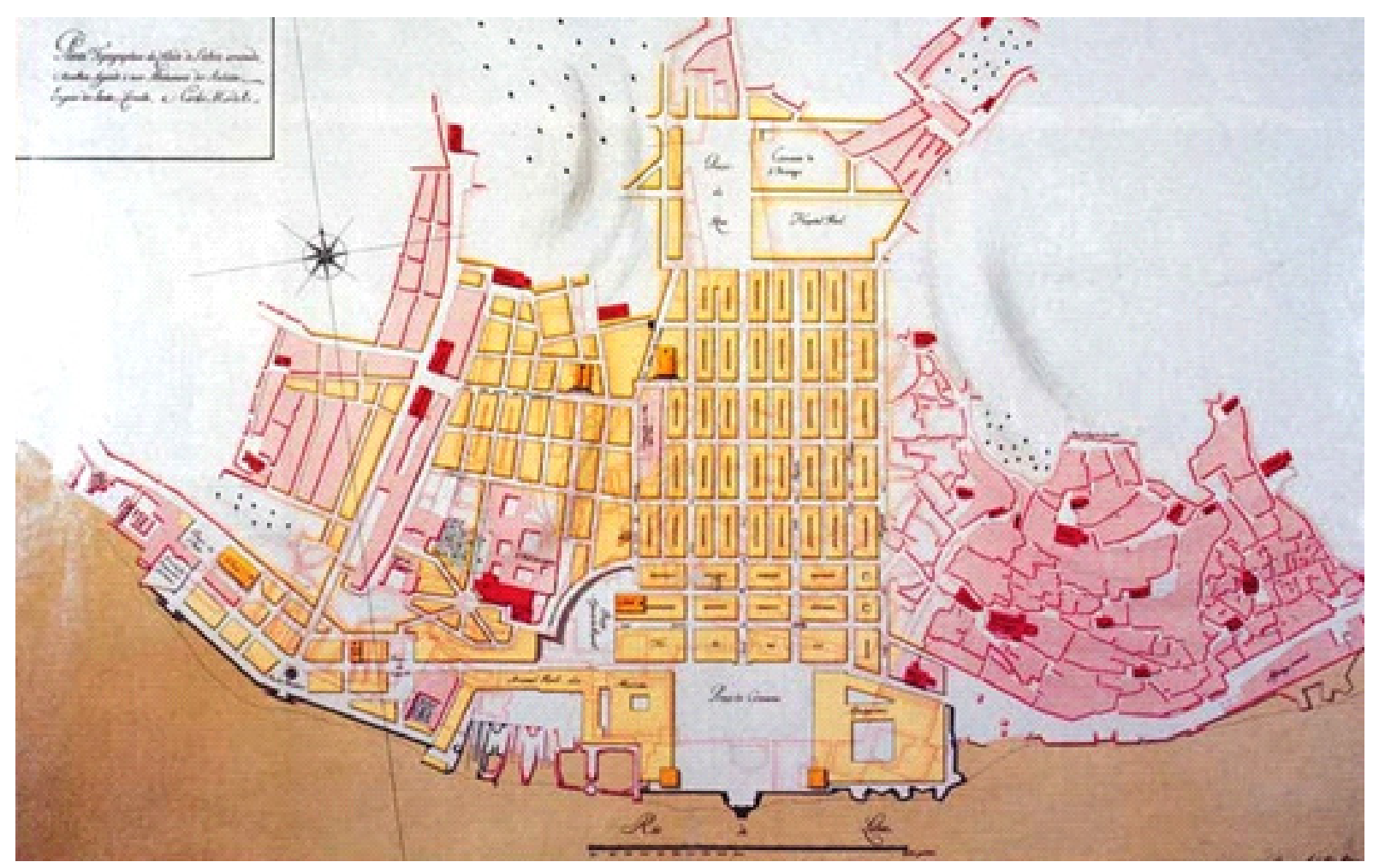

Figura 4 - Mapa com delimitação área da Baixa Pombalina.

Fonte: CML (2013). 
A pesquisa de campo inicia junto à Praça do Comércio e termina defronte à Praça do Rossio, figura 2.

A Praça do Comércio, antigo Terreiro do Paço, projetada segundo os princípios de Praça Real, para onde foi pensado o uso de arcadas e estátua, assim como o monumental arco do triunfo que coroa a composição desse conjunto de edifícios, sob a forma de uma ferradura e, ao centro deste complexo, esta estátua equestre do rei Joaquim Machado de Castro, figura 5.
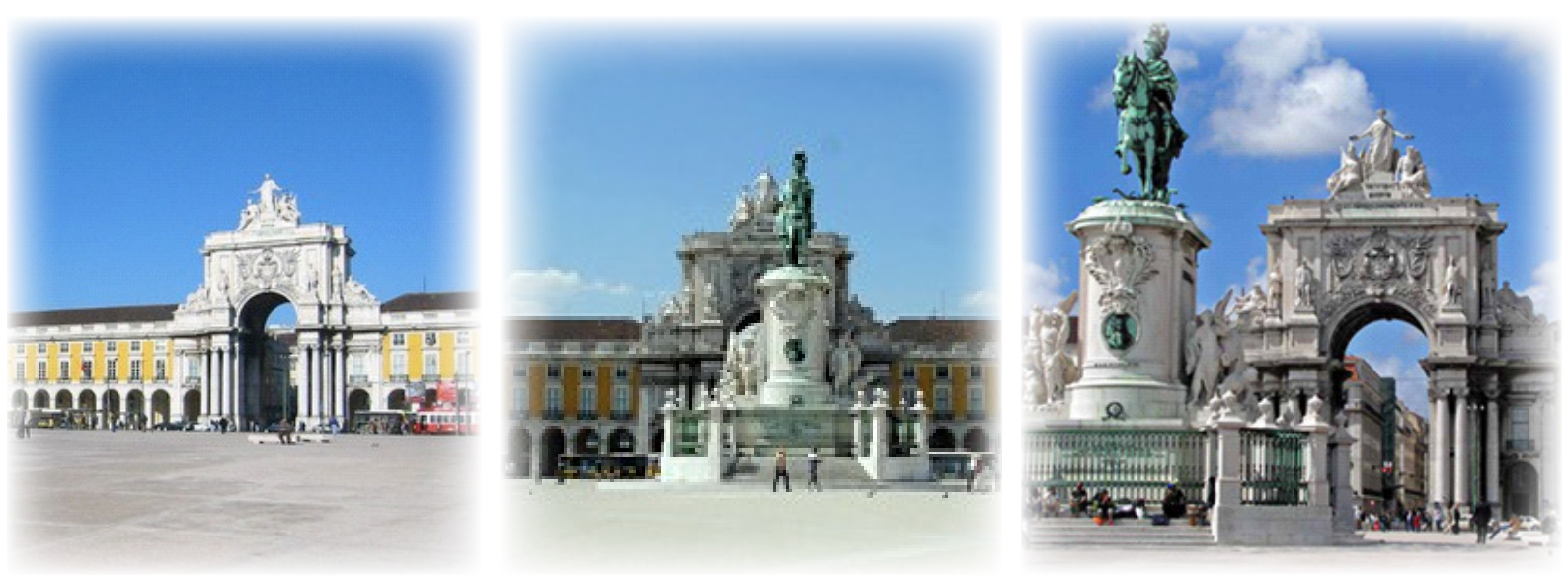

Figura 5 - Imagens do Arco do Triunfo, do edifício em forma de ferradura e da estátua equestre. Fonte: CML (2013). Informações adicionadas pelos autores (2014).

A ótica do local é de uma perspectiva grandiosa que se abre para o rio, após ter sido cercada por um conjunto de edifícios monumentais, sítio que foi e continua sendo o lócus de muitos acontecimentos, figura 6.

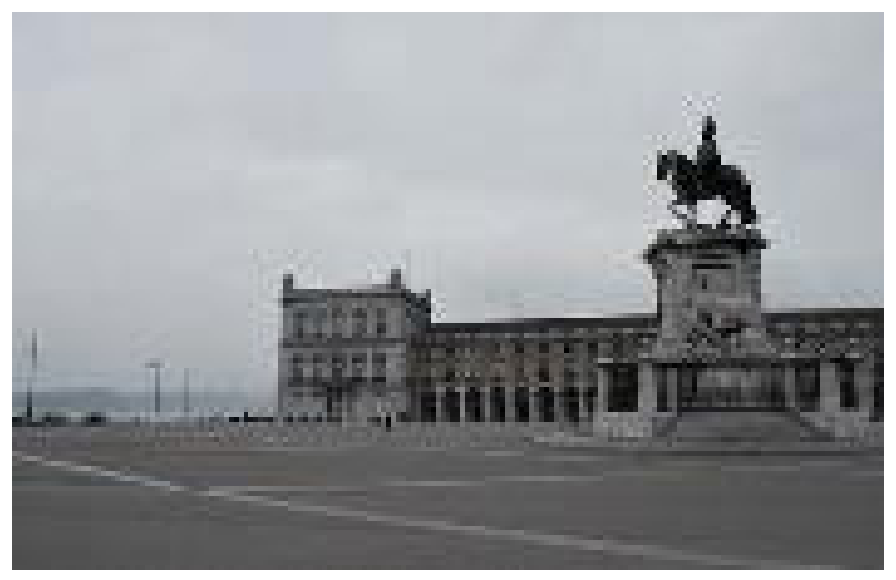

Figura 6 - Perspectiva grandiosa que se abre junto ao Rio Tejo.

Fonte: Ishizaka (2011).

Passando sob o Arco do Triunfo, inicia-se a Rua Augusta, trajeto 2 figura 7. A visão serial é de uma perspectiva velada em dois sentidos, devido à estatua e às edificações que circundam, e limita este grande eixo monumental, que culmina junto a Praça Dom Pedro IV, chamada de Rossio, um vazio urbano, núcleo de centralidade, lócus. 

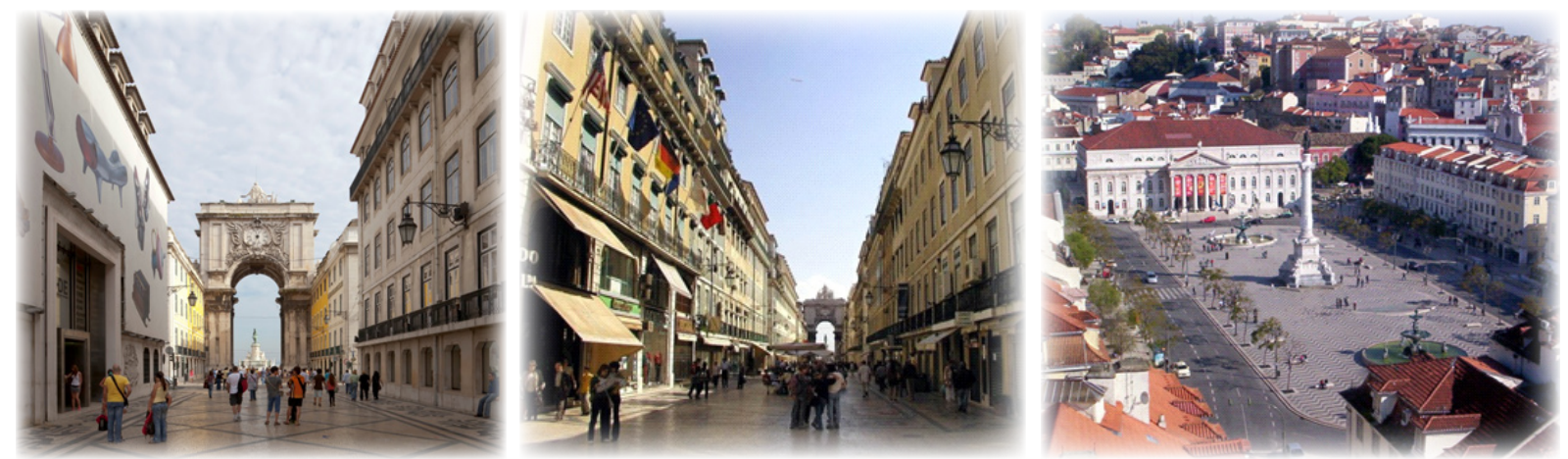

Figura 7 - Arco do Triunfo em direção a Rua Augusta até a Praça do Rossio.

Fonte: Ishizaka (2011).

Sob os arcos dos edifícios que circundam a Praça do Comércio, figura 8, há uma série de elementos repetitivos, arcos, ritmos que originam uma perspectiva velada, que promove a sensação de apropriação do espaço, paisagem interior que revela ricos elementos de ordem cultural. Esses edifícios que circundam a praça, sempre foram signos do poder governamental.

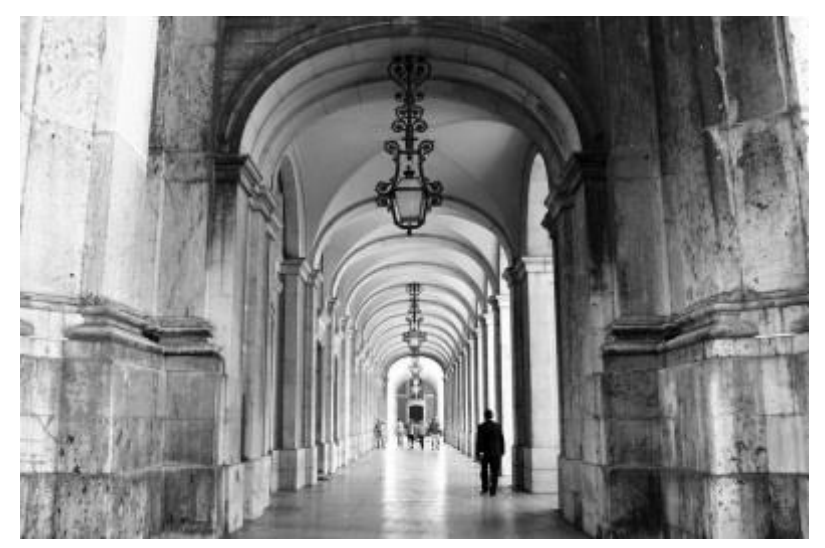

Figura 8 - Vista dos arcos internos dos corredores dos edifícios que circundam a Praça do Comércio.

Fonte: Ishizaka (2011).

Na Rua Augusta, à direita, surge a imagem de um elemento monumental, único, o elevador de Santa Justa, figura 9. Edificação que propicia visão serial de parte da cidade, iniciando pelo traçado reticular formado pelas vias, cuja hierarquia segue os preceitos do plano, assim como as edificações que as circundam. Ressalta-se a relação altura dos edifícios x largura da rua, estratégia adotada para evitar o efeito dominó, um edifício ruindo sobre o outro, em caso de abalos sísmicos. A largura das ruas deveria ser igual ou maior que a altura dos edifícios que a ladeavam. As casas foram construídas todas com a mesma altura, com quatro ou cinco pisos, com fachadas iguais e com uma estrutura para resistir aos sismos e evitar novos incêndios. Todas foram construídas sobre estacas de madeira, mergulhadas nas aguas do subsolo e entre os edifícios foram construídos muros corta-fogo para evitar a propagação das chamas (PESSOA, s/d ).

Ainda observa-se o limite, estabelecido pela topografia acidentada, que culmina junto à imagem do Castelo São Jorge, lócus do início da ocupação desse território e a vista dos telhados do plano pombalino, figura 9. 

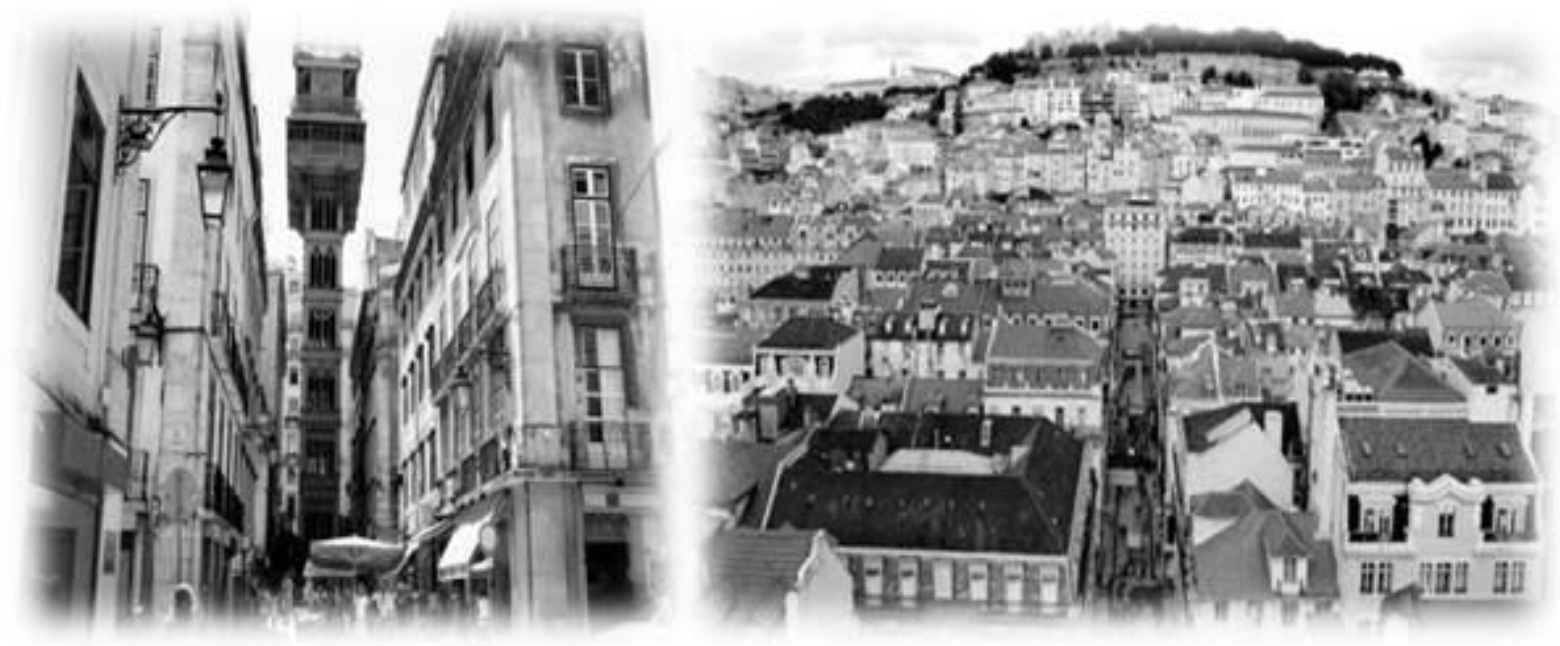

Figura 9 - Elevador de Santa Justa com os edifícios pombalinos, o traçado urbano, as coberturas pombalinas e o Castelo São Jorge.

Fonte: Ishizaka (2011).

Deste elemento icônico, o elevador, é possível ter uma visão serial das principais paisagens que circundam a Baixa Pombalina, fato que reforça a ideia de lócus. E também demonstra que a topografia e o rio são os principais elementos que estabelecem os seus limites e criam surpresas nessa paisagem.

A pesquisa de campo termina junto à Praça do Rossio, trajeto 3, perspectiva velada, praça de traçado barroco, com elementos monumentais, estátua, chafariz e edifício monumental ao fundo, figura 7.

É fato a preocupação constante com o turismo na cidade de Lisboa, pois são avaliados periodicamente os planos estratégicos para o desenvolvimento do Turismo, sendo que o vigente começou a ser implantado no ano 2011 e deverá ser concluído neste ano de 2014. Nele constam estratégias referentes a mercados, segmentos, produtos e marca. Também constam estratégias de marketing, relacionadas com imagem e comunicação, ou operacionais e de suporte, que orientam a infraestrutura, acessibilidade, recursos turísticos, recursos culturais e recursos humanos.
Este plano pretende que o setor turístico cresça em quantidade e valor, qualifique a experiência do visitante e aumente a notoriedade do destino. Dele faz parte a proposta de fazer renascer do Terreiro do Paço como ponto de encontro numa Praça Capital, ponto de partida de nossa pesquisa (SECRETARIA DE TURISMO DE LISBOA, 2011).

\subsection{Aplicação do método no centro históri- co de São Francisco do Sul (BR)}

Consta na história de São Francisco do Sul que, no século XVI, os franceses aportaram nessa cidade, no entanto seu processo de colonização inicia com as bandeiras paulistas em 1671 (PEREIRA, 1994). No ano de 1665, passou de Vila para Paróquia Nossa Senhora da Graça e, em 15 de abril de 1847, foi elevada a categoria de cidade (PREFEITURA MUNICIPAL DE SÃO FRANCISCO DO SUL, 2013).

A figura 10 demonstra as cidades que ocupavam o litoral brasileiro no período de implantação da $6^{a}$ Carta da Costa do Brasil. 


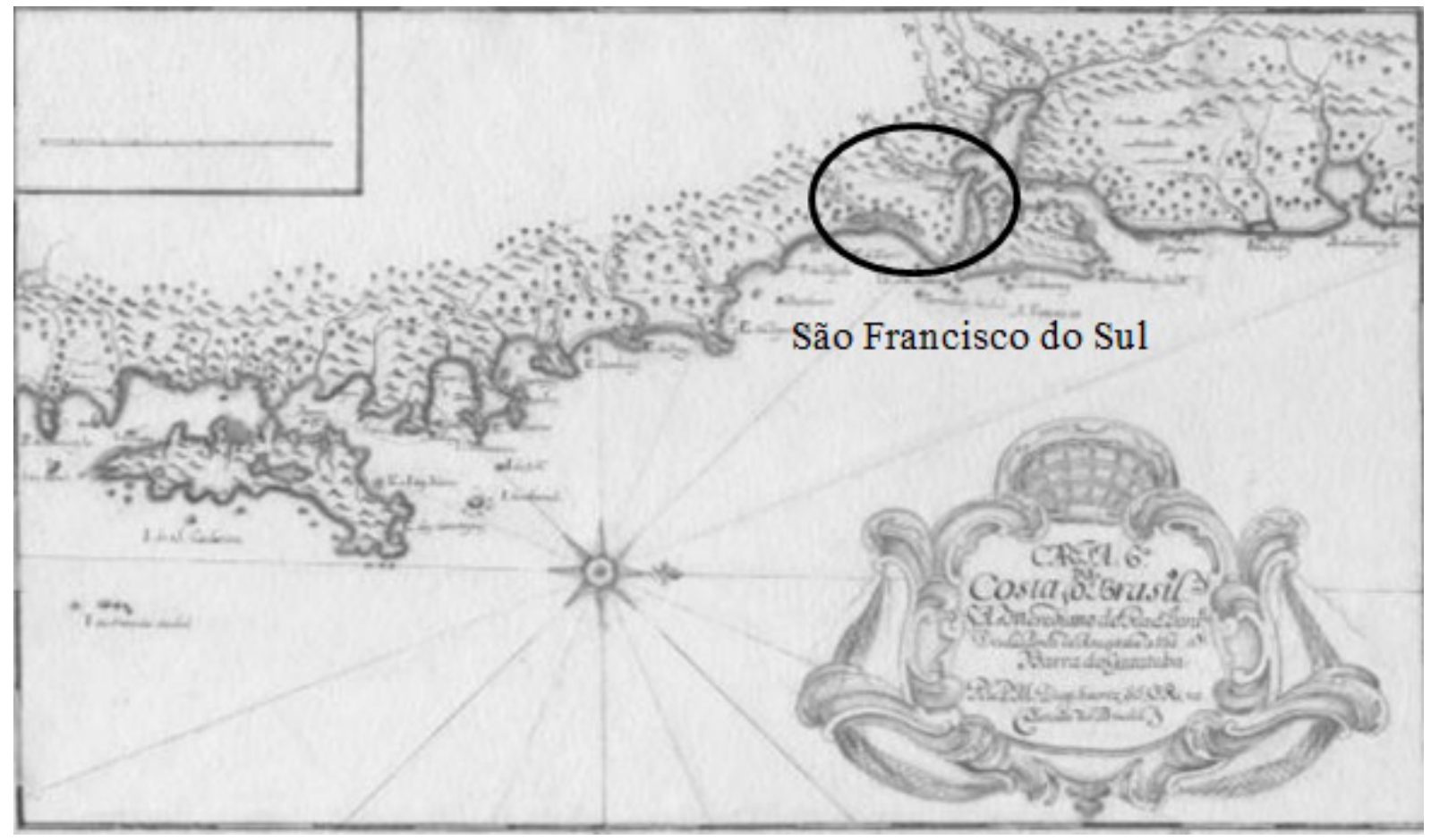

Figura 10 - Mapa da $6^{\text {a }}$ Carta da Costa do Brasil, desde a ponta de Araçatuba até a Barra de Guaratuba.

Fonte: IICT/AHU (s.d.). Informações adicionadas pelos autores (2014).

São Francisco do Sul, apesar de ter sido colonizado pelos vicentistas, tem a sua história vinculada à Baía da Babitonga, local que a conecta com o período das navegações portuguesas a partir do século XVI, e atualmente com o transporte de cargas nacionais e internacionais que acontecem pelo porto, principal atividade econômica.

Implantado sobre uma pequena elevação, o centro histórico, expressa as característica dos territórios ocupados pelos povos da antiguidade clássica. O arruamento se apresenta sob a forma de uma malha reticular, embora o traçado não seja ortogonal, devido à topografia ser acidentada, assemelha-se a malha urbana da Lisboa pombalina. A ocupação desse território segue os preceitos das Cartas Régias dos séculos XV, XVII e XVII, as quais ditam que o plano de ocupação deve adaptar-se às características morfológicas do terreno. Esse fato conferiu ao sítio físico uma ambiência de forte centralidade em relação ao núcleo urbano que ainda se faz presente (AUGUSTO-FRANÇA, 2009).

Vale ressaltar que, no século XVIII, as cidades eram construídas a partir de planos regulares, concebidos segundo traçados ge- ométricos, planejada racionalmente na sua estrutura global. A praça era o elemento central da malha urbana, os conceitos de planejamento e de beleza urbana estavam associados à simetria do traçado e à adaptação a modelos arquitetônicos uniformes, nela, na maior parte das vezes, se localizava o pelourinho, local onde também deveria ser edificada a igreja e a casa de Câmara e Cadeia. Todos os edifícios de habitação deviam ter fachadas construídas voltadas para a rua principal. Algumas cidades tinham mais de uma praça, destinadas a funções distintas, afirmando a continuidade da tradição das praças múltiplas das cidades portuguesas, uma delas ficava junto à igreja, com o cruzeiro, enquanto a outra se localizava próxima à casa da câmara e ao pelourinho (PEREIRA, 1994).

Em São Francisco do Sul (BR), os desenhos das ruas principais estão orientados paralelos à linha de costa, e as secundárias, cruzando-as, quase sempre, em ângulo reto. As ruas definem um conjunto de quarteirões retangulares orientados na direção do mar. Cada um desses quarteirões é constituído por duas filas de lotes urbanos organizados costas com costas. As frentes desses lotes estão 
voltadas para as ruas principais, não havendo lotes urbanos orientados para as ruas perpendiculares, todos os lotes são retangulares. Junto ao centro, essa a igreja, situada no meio de uma praça retangular, a qual corresponde pelas suas dimensões e pela sua relação com a restante malha urbana, a um quarteirão não construído. Este plano, expressa a manifestação dos princípios barrocos sobre o planejamento medieval, modelo que foi aplicado em Portugal, no Brasil e no Oriente, figura 11 (OLIVEIRA, 2010).

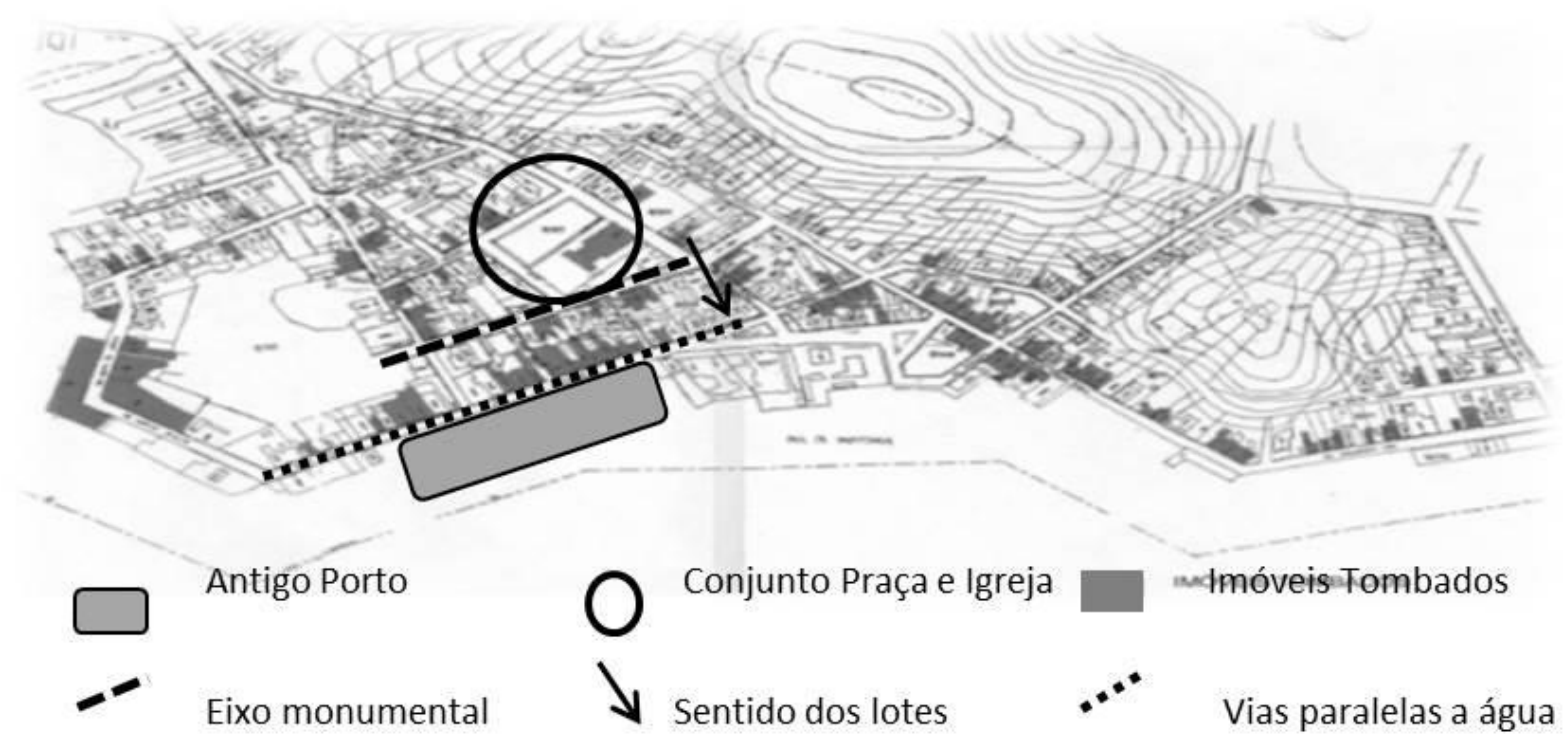

Figura 11 - Mapa da Cidade de São Francisco do Sul (BR).

Fonte: Acervo do ETEC-SFS-IPHAN (PREFEITURA MUNICIPAL DE SÃO FRANCISCO DO SUL, 2010). Informações adicionadas pelos autores (2014).

A pesquisa de campo inicia junto ao Mercado Público, área-estudo, figura 12, ponto nodal, logradouro, ótica, local.

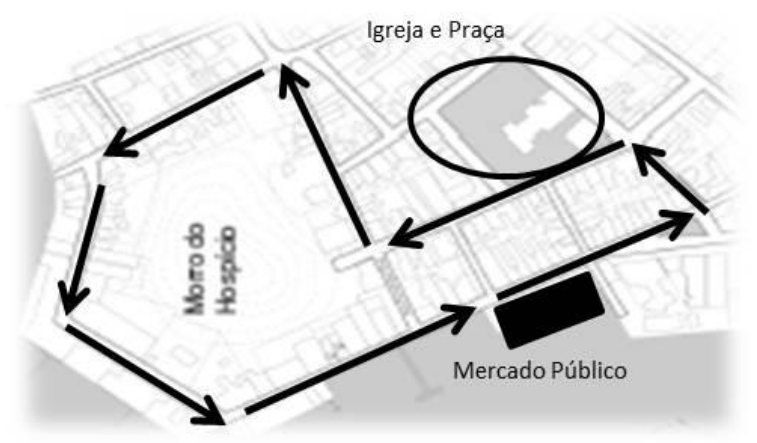

Figura 12 - Percurso da pesquisa de campo. Fonte: Acervo do ETEC SFS IPHAN (PREFEITURA MUNICIPAL DE SÃO FRANCISCO DO SUL,

2010). Informações adicionadas pelos autores (2014).
O edifício do Mercado Público, figura 13, foi construído no ano de 1900 (IPHAN, 2009) contrasta junto a paisagem de borda da baía, a perspectiva é grandiosa, uma iniciativa local, um enclave, que aponta uma sucessão de pontos de vista, ótica. Ao transpassar o pórtico, há uma apropriação do espaço, cuja paisagem interior revela um recinto rico em elementos de ordem cultural, sua arquitetura é rica em pormenores, conteúdo, com detalhes em ferro e cimalhas de argamassa. Esse edifício reduz a magnitude de sua paisagem, perspectiva velada, quando volta às costas para a baía. 

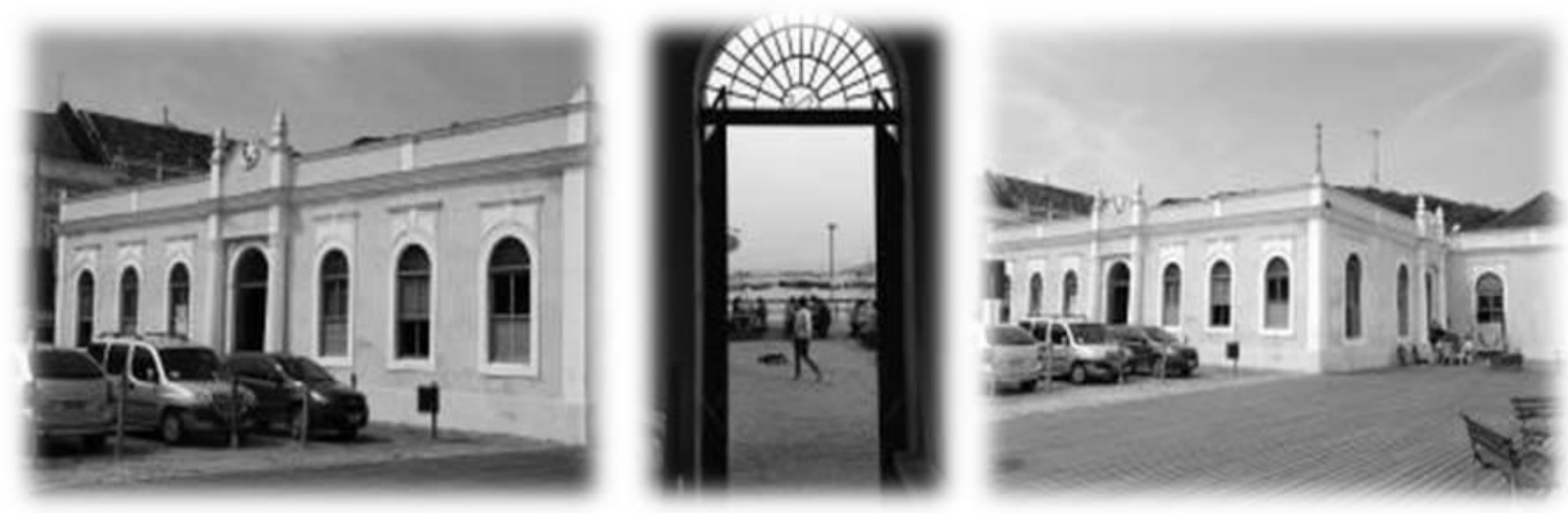

Figura 13 - Mercado Público, fachadas e pórtico.

Fonte: Acervo próprio (2013).

O gabarito da via promove o estreitamento do visual com uma perspectiva delimitada, ótica. Alguns sobrados, loja no térreo e residência no pavimento superior, área-residência, ocupam toda fachada do terreno, construídas sobre o alinhamento da via pública e sobre os limites laterais. A tipologia de ocupação dos lotes é em fita, e os edifícios são de arquitetura eclética, estilo arquitetônico típico do início do século XIX, figura 14 (REIS FILHO, 1970).
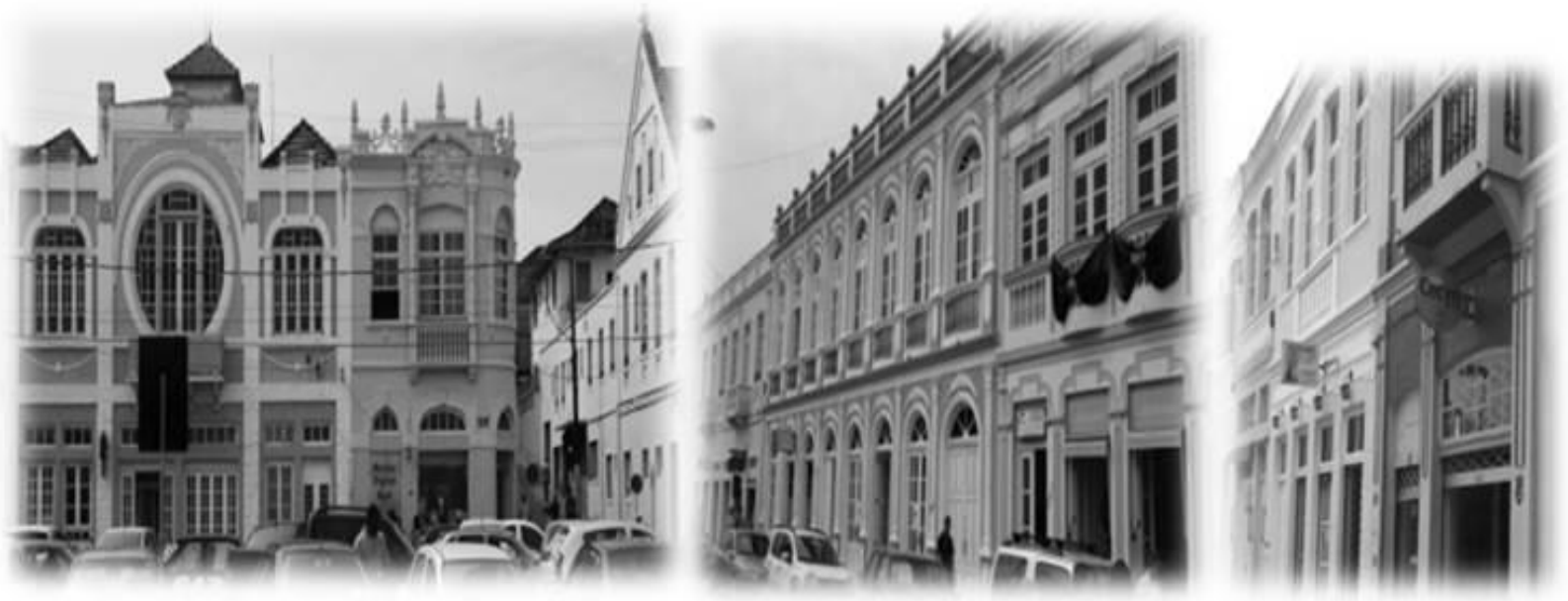

Figura 14 - Conjunto de edifícios que compõe o lado oposto à baía.

Fonte: Acervo próprio (2013).

A via de acesso à parte alta da cidade, não dá continuidade à malha reticular devido à topografia ser acidentada, a sensação é de que se perde a noção do todo e observam-se as partes. Surgem elementos que criam um efeito de silhueta, conteúdo e local. Contrastando com essa paisagem, está um edifício, posto de gasolina, de tipologia arquitetônica racionalista (REIS FILHO, 1970) típica do início do modernismo no Brasil. Este enclave, conteúdo que culmina em uma edificação com arquitetura repleta de ornamentos, com aberturas em arco, cimalhas dividindo o pavimento térreo do superior, guarda corpo de ferro semelhante às tipologias de edificações descritas na regulamentação da cidade pombalina de Lisboa. À medida que a inclinação aumenta, a rua se fecha, cria uma perspectiva velada, figura 15. 

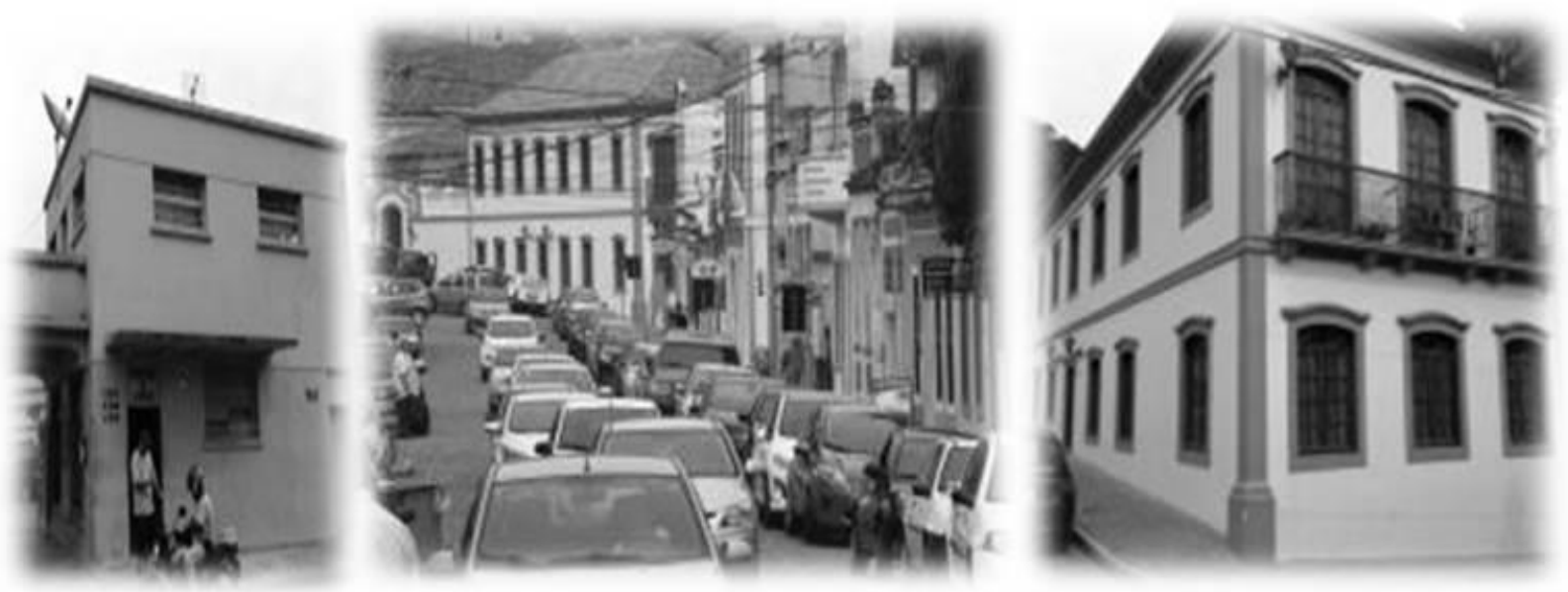

Figura 15 - Edifício modernista, perspectiva velada e edifício típico da regulamentação pombalina.

Fonte: Acervo próprio (2013).

Ao dobrar a esquina, aparece um contraste súbito, o campanário da Igreja Nossa Senhora das Graças (1655), um ponto focal, nodal, um marco devido a sua morfologia, que confere a monumentalidade ao edifício, como uma escultura. Sua construção iniciou

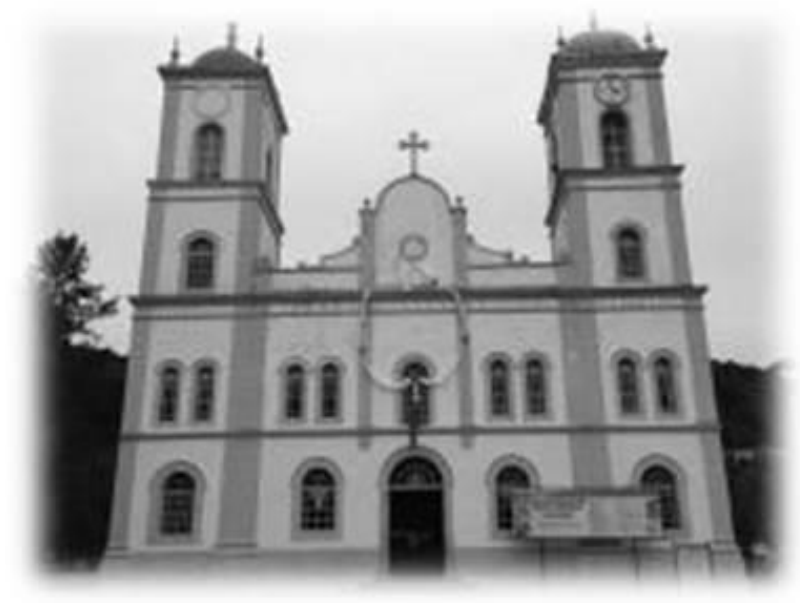

em 1699, com argamassa composta de cal de concha, areia e óleo de baleia, originalmente construída em estilo veneziano e com uma só torre, no entanto passou por diversas modificações, em 1921 foi construída a segunda torre, figura 16.

Figura 16 - Igreja Nossa Senhora das Graças e Praça e Praça Getúlio Vargas.

Fonte: Acervo próprio (2013).

Junto ao largo da Igreja, está a Praça Getúlio Vargas, lócus cujo tipo de implantação segue os moldes das cartas régias portuguesas do período barroco (AUGUSTO-FRANÇA, 2009). Há uma massa de vegetação que promove o fechamento, limite, conteúdo que individualiza a paisagem, pois promove o contraste entre os dois lados da via, um fechado e o outro, reple-

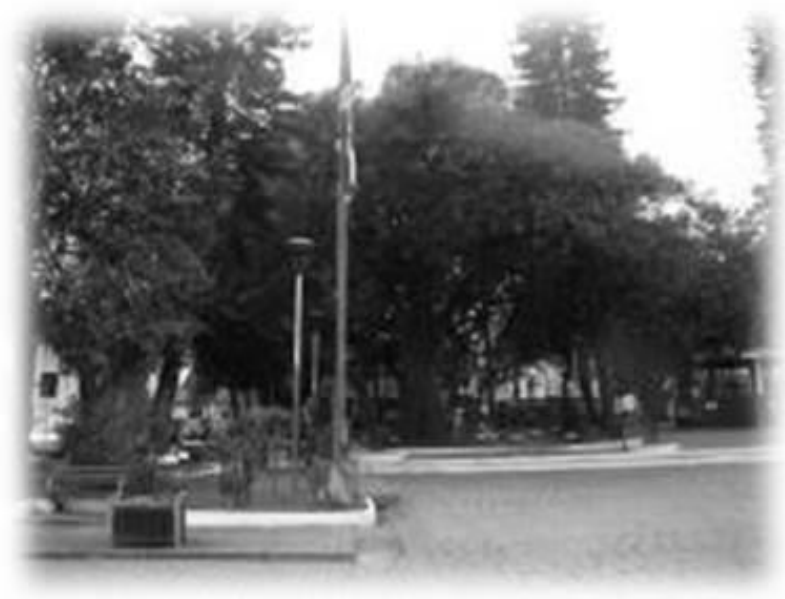

to de edificações construídas ao rés do chão, ocupando todo o lote, sendo uma implantada junto a parede limite da outra, figura 16 .

Esses edifícios que foram construídos ao rés do chão, possuem tipologia arquitetônica típica do período colonial, com um acesso principal, duas janelas e ocupação do lote em fita (REIS FILHO, 1970), figura 17. 

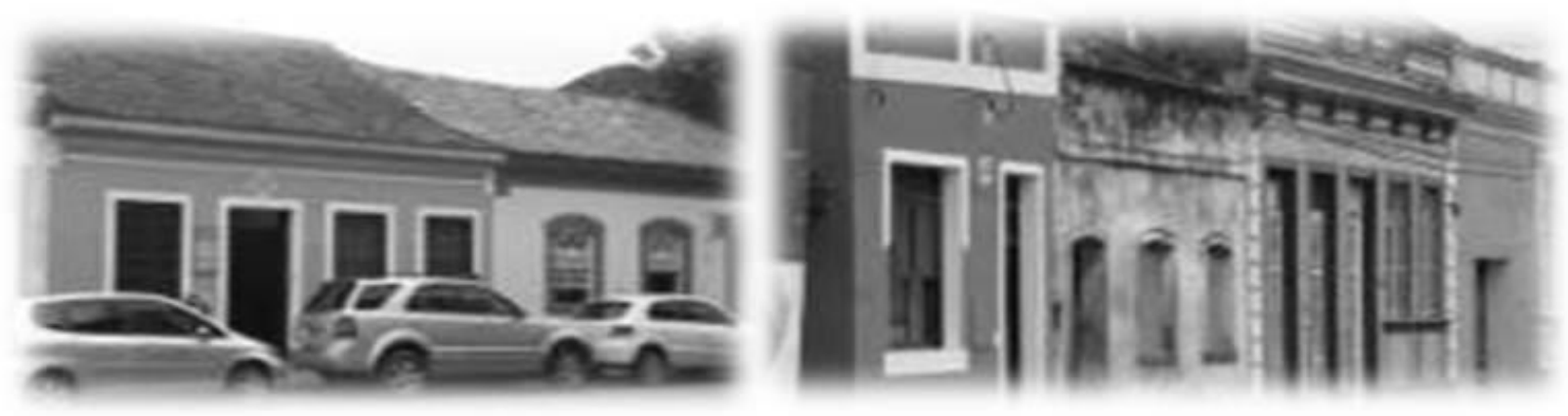

Figura 17 - Igreja Nossa Senhora das Graças e Praça e Praça Getúlio Vargas.

Fonte: Acervo próprio (2013).

O Museu do Mar, figura 18, antigo armazém, lócus, primeiro do gênero no Brasil, instalado em setembro de 1991 e inaugurado em dezembro de 1992. O local abrigava anteriormente o conjunto de depósitos e escritórios da antiga Empresa de Navegação Hoepke, construídos no fim do século XVIII. O edifício é de arquitetura eclética, com influência alemã, possui uma impressionante estrutura de madeira, é uma das mais antigas edificações da cidade (IPHAN, 2009). É uma construção de caráter monumental, um marco cuja configuração gera uma perspectiva velada, em virtude da disposição dos edifícios que formam esse conjunto. Essa perspectiva se torna grandiosa ao dobrar a esquina, com a visualização da Baia da Babitonga, ótica, limite, borda.
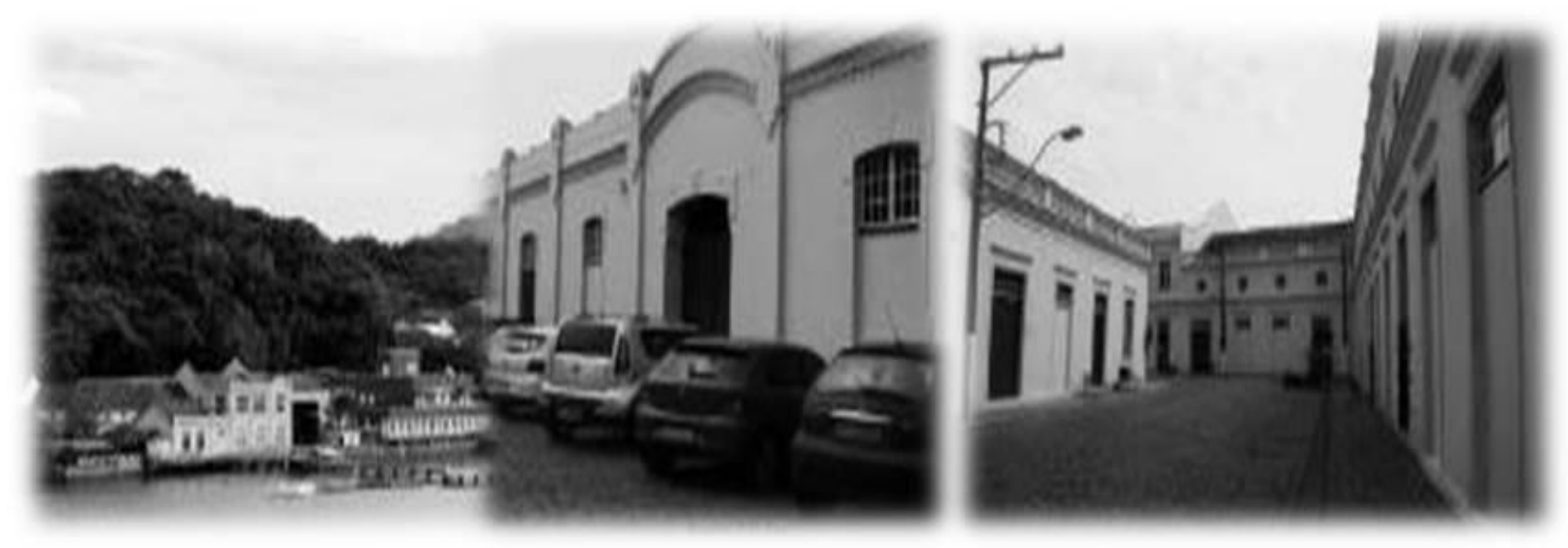

Figura 18 - Baía da Babitonga e Museu do Mar.

Fonte: Acervo próprio (2013).

Às margens da baía, o edifício que se destaca é o do antigo Clube XXIV de Janeiro, figura 19, construído em 1905, conserva fortes traços do estilo do período colonial. O intuito do projeto, elaborado por Marcos Gorresen e Jose Augusto Nobrega, era que os ambientes fossem requintados para atender as atividades culturais e sociais. Sofreu reformas para abrigar o Cine Radium em 1950. Dos traços originais da edificação - arquitetura em estilo eclético - pouco resta além da fachada principal e as paredes periféricas. No pavimento térreo atualmente, estão algumas lojas e, no segundo pavimento, há um grande salão (IPHAN, 2009). 

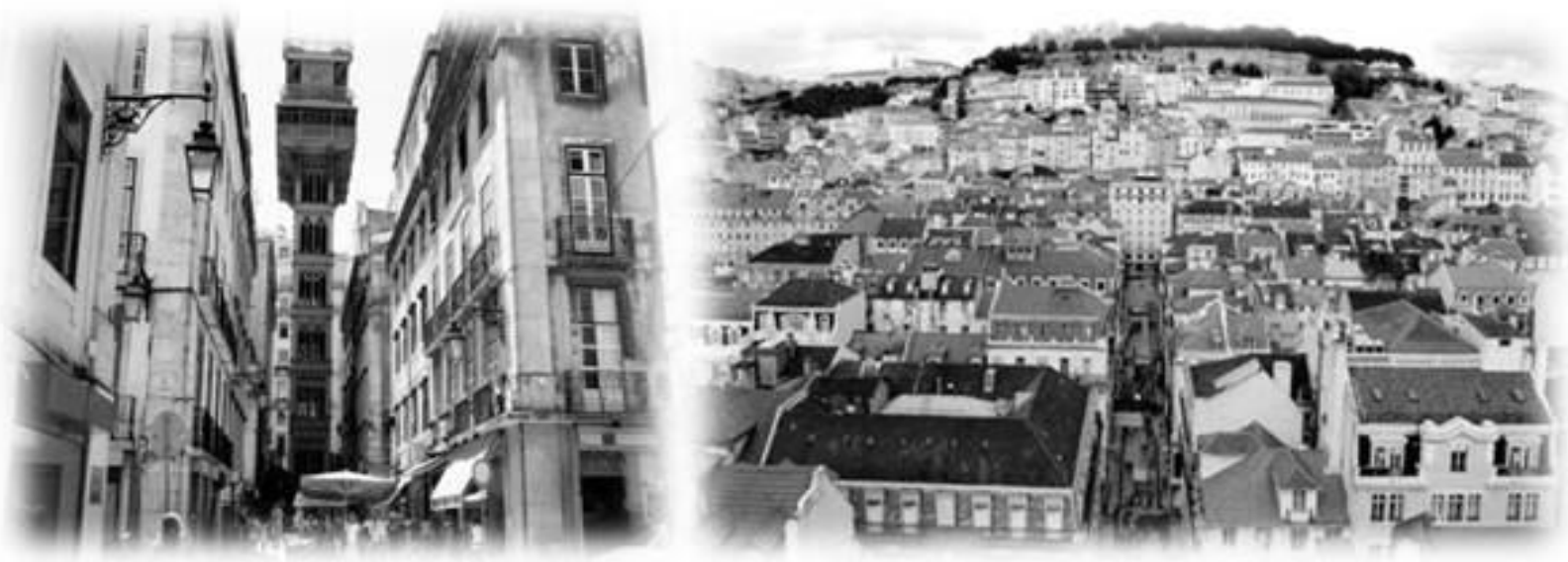

Figura 19 - Clube XXIV de Janeiro e o conjunto de edifícios.

Fonte: Acervo próprio (2013).

\section{ANÁLISE DOS DADOS}

Esta investigação parte do princípio de que, para compreender a morfologia urbana, é primordial conhecer o ponto de partida das cidades. "[...] Sem saber onde estivemos, é difícil saber para onde vamos. [...]" (ROSSI, 1995). Sendo assim, o início da investigação parte do rio, marco de desenvolvimento econômico dessas cidades.

O porto sempre foi a principal atividade econômica dessas cidades, as ligações, por meio da navegação, eram imprescindíveis para a proteção do território e conexão com Lisboa, relacionando assim, todo o desenho da cidade a sua orla marítima. O conjunto que compõe a essa área estudo caracteriza-se como um bairro, devido as suas similaridades morfológicas urbanas e arquitetônicas.

Sendo assim, pode-se observar que, na primeira região, Baixa Pombalina (PT), todas as categorias de análise da paisagem foram identificadas, portanto confirmamos o que a bibliografia registra, ou seja, que esta é uma área onde o turismo cultural já se encontra consolidado, devido a sua rica paisagem composta pelo patrimônio histórico edifi- cado e pelo conjunto de investimentos que estruturam os projetos para a manutenção e desenvolvimento do turismo cultural em Portugal (SECRETARIA DE TURISMO DE LISBOA, 2011)..

E, no centro histórico de São Francisco do Sul (BR), foi possível verificar que a vida urbana iniciou com a ocupação portuguesa no século XVII, pois muito do que foi lido nessa cidade data dessa época e também de períodos posteriores a ela. Nela não encontramos muitas praças, nem monumentos centrais ao eixo principal, fato que provavelmente se deve às características topográficas do terreno e às modestas condições econômicas da sociedade da época. Se esses achados forem comparados à realidade das cidades portuguesas em Portugal, como afirma Bicca e Bicca (2008), as intervenções barrocas nas cidades brasileiras apresentam um caráter monumental mais acanhado.

A tabela 1 apresenta as categorias de análise da paisagem identificadas na Baixa Pombalina, Lisboa (PT) e no centro histórico deSão Francisco do Sul (BR), nele foram registradas e compiladas as informações coletadas durante a pesquisa de campo. 
Tabela 1 - Síntese das categorias de análise da paisagem identificadas durante a pesquisa de campo na Baixa Pombalina, Lisboa (PT) e centro histórico de São Francisco do Sul (BR).

\begin{tabular}{|c|c|c|}
\hline Categorias & Baixa Pombalina & Centro Histório S.F.S. \\
\hline Conteúdo & $\mathrm{x}$ & $\mathrm{x}$ \\
\hline Ótica & $\mathrm{x}$ & $\mathrm{x}$ \\
\hline Local & $\mathrm{x}$ & $\mathrm{x}$ \\
\hline Lócus & $\mathrm{x}$ & $\mathrm{x}$ \\
\hline Área estudo & $\mathrm{x}$ & $\mathrm{x}$ \\
\hline Área residência & $\mathrm{x}$ & $\mathrm{x}$ \\
\hline Bairro & $\mathrm{x}$ & $\mathrm{x}$ \\
\hline Limite & $\mathrm{x}$ & $\mathrm{x}$ \\
\hline Borda & $\mathrm{x}$ & $\mathrm{x}$ \\
\hline Lotes & $\mathrm{x}$ & \\
\hline
\end{tabular}

Fonte: Acervo próprio (2014).

Ao associar esses apontamentos, foi possível observar que, nas duas áreas estudadas, foram encontradas as mesmas categorias de análise da paisagem. As diferenças relevantes estão apenas nas proporções das monumentalidades, pois, em São Francisco do Sul, tudo é muito modesto, as atividades econômicas e sociais da época não estavam ligadas a uma grande produção de bens materiais, fazendo com que o montante destinado aos investimentos urbanos fosse pequeno, embora garantindo a presença do cerne que caracteriza a cidade portuguesa do século XVII fora de Portugal.

\section{CONSIDERAÇÕES FINAIS}

Fica claro que São Francisco do Sul (BR) é uma cidade brasileira que possui potencialidades para o desenvolvimento do turismo cultural, em virtude do rico patrimônio histórico edificado, o qual demonsta que ela é uma cidade que foi construída aos moldes da Baixa Pombalina, Lisboa (PT). Mas também percebe-se que todo esse diferencial está sendo desperdiçado, perdido, pois os planos turísticos atuais desta cidade enfatizam apenas as praias e o desenvolvimento do turismo de sol e mar, enaltecendo-os como o maior potencial para o desenvolvimento econômico da região, deixando de lado os planos e investimentos para a preservação e recuperação do seu patrimônio histórico. Pouco do que é realizado em prol desses bens materiais são iniciativas do Instituto do Patrimônio Histórico e Artístico Nacional, que a duras penas vem realizando ações de restauro.

Os empreendedores imobiliários dessa região ainda não compreendem que podem tirar partido dessas ricas áreas, dando novos usos a esses espaços, preservando a memória e a identidade dessa sociedade, em vários períodos de sua história. E obtendo lucro, pois, hoje, os espaços que mantém a sua autenticidade são cobiçados pela indústria do turismo.

Infelizmente, a realidade atual é de que muito desse patrimônio edificado anoitece, mas não amanhece, pois, enquanto a população brasileira não compreender que manter o patrimônio edificado é perpetuar a sua história, é posicionar-se fortalecendo os movimentos sociais em prol dessa causa, muitos bens materiais históricos serão dizimados e, junto com eles, irão o patrimônio imaterial, que sem referências acabam sendo esquecidos.

São Francisco do Sul é uma dessas cidades, onde os planos turísticos enfatizam as praias, o desenvolvimento do turismo de sol e mar, o qual ainda é visto como o maior potencial para o desenvolvimento econômico da região, deixando de lado os investimentos para a preservação e recuperação do seu patrimônio histórico. Pouco do que é feito, parte da iniciativa do Instituto do Patrimônio Histórico e Artístico Nacional, que a duras penas vem realizando ações de restauro. 
Ao divulgar esses conhecimentos, esperamos poder contribuir com os gestores, responsáveis pela elaboração de políticas públicas, estimulá-los para que elaborem ações que mobilizem a sociedade em prol do desenvolvimento do turismo cultural e da preservação, recuperação do patrimônio histórico edificado, para que a história das cidades brasileiras possa ser conhecida pelas gerações do futuro.

\section{REFERÊNCIAS}

AUGUSTO-FRANÇA, José. Lisboa - história física e moral. Portugal: Livros Horizonte, 2009.

ARGAN, Giulio Carlos. Projeto e destino São Paulo: Atica, 2001.

BICCA, Paulo; BICCA, Briane. Arquitetura na formação do Brasil. 2. ed. Brasília: UNESCO, Instituto de Patrimônio Histórico e Artístico Nacional, 2008.

BOULLÓN, Roberto. Planejamento do espaço turístico. Bauru, São Paulo: EDUSC, 2002.

CÂMARA MUNICIPAL DE LISBOA. 2013. Disponível em: <http://www.cm-lisboa.pt/>. Acesso em: fev. 2014.

CULLEN, Gordon. Paisagem urbana. Lisboa: Edições 70,1971

DIOGO, Érica (Org.). Recuperação de imóveis privados em centros históricos. Brasília, DF: IPHAN/Programa Monumenta, 2009. Disponível em: <http://portal.iphan. gov.br/uploads/publicacao/ColReg_RecuperacaoIm oveisPrivadosCentrosHistoricos_m.pdf $>$.

INSTITUTO DO PATRIMÔNIO HISTÓRICO E ARTÍSTICO NACIONAL (IPHAN). Patrimônio, desenvolvimento e cidadania - PAC cidades históricas. Brasil, 2009.vel em: <http://portal.iphan.gov.br/portal/montarPaginaSecao.do?id=14926\&retorno=paginaIphan $>$.

INSTITUTO DE INVESTIGAÇÃO CIENTIFICA TROPICAL/ARQUIVO HISTÓRICO ULTRAMARINO (IICT/ AHU). Mapa da $6^{a}$ Carta da Costa do Brasil, desde a ponta de Araçatuba até a Barra de Guaratuba. Lisboa, [s.d.].

ISHIZAKA, Gloria. Imagens de Lisboa. 2011. Disponível em: <http://gloriaishizaka.blogspot.pt/2011/06/ portugal-baixa-de-lisboa.html>. Acesso em: jan. 2014.

LYNCH, Kevin. A imagem da cidade. São Paulo: Martins Fontes, 1997.
MUSEU DA CIDADE. Exposições. Exposição Permanente. O terramoto de 1755 e a reconstrução (séc.XVIII/ XIX). 2013. Disponível em: <http://www.museudacidade.pt/Esposicoes/Permanente/Paginas/Terramoto-de-1755-Reconstrucao-sec-XVIII\% E2\% 80\% 93XIX. aspx>. Acesso em: jan. 2014.

NORMAN, Aguilar Gallegos; ALEJANDRO, Velásquez Álvarez. Manual introdutório a analise de Redes Sociais. 2006. Disponível em: <http://docplayer.com. br/4895662-Manual-introdutorio-a-analise-de-redes-sociais.html>.

OLIVEIRA, Andréa. Cá e lá, histórias há: mitos e símbolos nas lendas de São Francisco do Sul e da Ilha da Madeira. 2010. Dissertação (Mestrado em Patrimônio Cultural e Sociedade) - Universidade da Região de Joinville, Joinville, SC.

PEREIRA, Antônio. Lisboa Barroca. Da restauração ao terramoto de 1755: a vida e a mentalidade. Do espaço, do tempo e da morte. Lisboa: Horizonte, 1994.

PESSOA, João. Cidade barroca ou tardo medieval? A arquitetura na definição dos traçados urbanos da América portuguesa. [s./d.]. Universidade Federal Fluminense. Brasil. Disponível em: <http://www.upo.es/depa/ webdhuma/areas/arte/3cb/documentos/089f.pdf $>$. Acesso em: jan. 2014.

PORTAS, Nuno. A cidade como arquitetura. 4. ed. Lisboa: Livros Horizonte, 2011.

PREFEITURA MUNICIPAL DESÃO FRANCISCO DO SUL. ETEC-SFS-IPHAN. Plano de Preservação do Patrimônio Histórico de São Francisco do Sul. São Francisco do Sul, SC, 2010.

REIS FILHO, Nestor Goulart. Quadro da Arquitetura no Brasil. São Paulo: Perspectiva, 1970.

ROSSI, Aldo. A arquitetura da cidade. 2. ed. São Paulo: Martins Fontes, 1995.

ROSSINI, Diva de Mello. A Barroca Lisboa (PT) e o centro histórico de São Francisco do Sul (BR). 2014. Relatório de estágio pós-doutoral. Programa de Doutoramento e Pós doutoramento em Arquitetura - Universidade de Lisboa (PT).

SECRETARIA DE TURISMO DE LISBOA. O Plano Estratégico para o Turismo de Lisboa 2011-2014. Publicado em 2011. Disponível em: <http:/ /www.cafeportugal.net/ resources/3/files/plano\%20estrategico.pdf $>$. Acesso em: nov. 2013.

YAZIGI, Eduardo. A alma do lugar. São Paulo: Contexto, 2001. 